\title{
PHENOMENAL FORMS OF FRAUD IN SYSTEM OF INDIRECT TAXATION
}

\section{Elvir Sačić ${ }^{1}$}

Indirect Taxation Authority of Bosnia and Herzegovina

Received: 29.05.2011

Accepted:12.11.2011
UDC: 334.359 .2

336.225 .68

\begin{abstract}
This work could be summarized by unique description: it is phenomenological analysis designed to determine and analyze the concept of crimes against financial interests, i.e. budgetary funds of Bosnia and Herzegovina as well as of the European Union. Through a syn- thetic and casuistic description of individual phenomenological forms of criminal actions and the systematisation of them according to given criminological characteristics, an endeavour is made to delve into the complex fiscal, financial, economic and legal context in which these deeds arise, and to associate them more closely with the practical reality. In order to bring to light the multidimensional importance and throw light on crime against the budget of the Bosnia and Herzegovina and the EU from several aspects, in this paper a phenomenological analysis is carried out at several levels and is based on main criteria: the phenomenological forms considering the kind of legally protected good-the revenues and/or expendituresof the budget
\end{abstract}

Key words: phenomenology', indirect taxation system.

\section{INTRODUCTION}

Tax evasion in general represents activities and Considering the fact that taxpayer is obliged to failure to comply with new activities that taxpayer carries out in order to evade tax payment (Dautbašić, pay the tax, failure to do so will result in enforced 2004, p. 161). Tax evasion is result of taxpayer endeveors that are aimed to lower tax burden. It is a direct result of "embedded" resistance of taxpayer defraudation ${ }^{3}$, even risking high penalties. towards tax payments.

\section{Correspodence to:}

Elvir Sačić, MSc, Indirect Taxation Authority of Bosnia and Herzegovina.

Sarajevo, B\&H

Phone: +387 62962093

E-mail: elvir.sacic@uino.gov.ba

2 From Greek word "fainomai" which means "I appear". It is a part ofcriminological science that deals with the forms in which criminal behaviour appears together with their description and systematisation.

3 Defraudation represents tax evasion by false evidence and bookkeeping in markets, craft shops, law offices, medical and other companies with the aim to show false expenses and total income and to lower tax liability. (Dautbašić, 2004, p. 161). 
Tax evasion usually leads to a redistribution of tax burden in the society in relation to burden sharing that was predicted by legislator, because tax was not paid exactly by the person that is supposed to be taxpayer. If we have clearly fiscal goals of taxation, tax evasion would force the government to increase other taxes in order to secure enough public funds. Typical example of abovementioned was tax system in Bosnia and Herzegovina.

It was manifested in poor application and enforcement of Law on movement of goods and services. Collection of taxes that were associated to this law was linked to the numerous problems and difficulties. Solution of the problem was new Law on value added tax. With this system, many puzzles fell into their place, whereby fiscal moment that is manifested through increase in tax collection came to the light.

\section{FORMS OF INDIRECT TAX EVASION}

From a legal standpoint, we can differentiate concepts of legal and illegal tax evasion. Demarcation line between tax evasion and avoidance of taxes is illegality of the behavior. In practice, there are many grey areas in which is very difficult to draw a sufficient and clear line. This often leads tax authorities to qualify certain cases insufficiently.

Legal avoidance of taxes - includes behavior of taxpayer aimed at lowering of tax liability by using all legally permissible options. Core of this mechanism is so called tax planning.

In practice, these are most common methods of legal evasion: Finding holes in law or loopholes, abstention from consumption, substitution, business reorientation, change of temporary residence, change of company headquarters and area of activity, vertical concentration, marketing expenditure, humanitarian aid, change of citizenship, investment, change of form of capital, movement to tax oasis, establishing offshore companies. These behaviors of taxpayer are considered as "acceptable" ways of tax evasion unlike "unacceptable" legal evasion that is subject to sanctions in developed countries. Term "legal evasion" represents activities that do not have business or economic goal as their main purpose, but obtaining tax benefits. Demarcation line between these two modalities of legal evasion is very fluid because it is very difficult to draw precise line between skillful management and abuse of rights in tax matters.

Illegal tax evasion - represents immediate breach of tax laws when a taxpayer consciously and purposely avoids existing tax liabilities. Disrespect of tax regulations in most legal systems is qualified as tax offence, economic crime or felony. Range of illegal behaviors in the enforcement of tax liabilities basically reflects level of fiscal indiscipline of taxpayers.

Procedures and actions of the taxpayers aimed at avoidance or reduction of tax liabilities are identical in cases of tax evasion and other tax offences.

What separates these two offences is amount of evaded taxes. For this purpose, taxpayers use double-entry accounting, false documents, and opening of business accounts fictitious persons, moonlighting, payment in kind etc...

Punishable acts that cause damage to the state budget are, in the literature and in practice usually called frauds or irregularities. This term is used to indicate act of felony in penal code, as well as minor offences against the budget such as economic offences. 
In the EU, the concept of irregularity is defined by Council regulation on the protection of the European Communities financial interests (1995, No 2988/95, hereinafter: Council regulation). It is accepted, not only in scientific literature, but also in the Community law (Council regulation, 1995, No 2988/95, Article 1, paragraph 1), and state members' laws. It is designated according to the criteria whether the revenue or expenditure of the EU is "attacked".

Type of indirect taxes, place and occurrence of tax liabilities are main criteria used to differentiate irregularities. In this sense, there are duties that occur in foreign trade of goods and services (custom fees, import excise duties, tariff quotas, import value added tax, subsidies) and duties in domestic movement of goods and services (value added tax, domestic excise duties).

\section{IRREGULARITIES IN CUSTOMS SYSTEM}

One of the basic frauds that damages budget of Bosnia and Herzegovina and the EU is avoidance of import duties (customs charges, import excise tax, import value added tax and etc...) and false presentation of export contracts and businesses. Apart from these irregularities, there are also evident offences related to subsidies i.e. illegal usurpation of state aid and expenditures. This is a criminal conduct by which taxpayers misuse or misappropriates different kinds of subsidies, incentives, bonuses and other forms of budgetary expenditure).

\section{AVOIDANCE OF IMPORT DUTIES}

Council of Ministers of Bosnia and Herzegovina and other institutions in Bosnia and Herzegovina adopt laws ${ }^{4}$, bylaws on customs and custom fees, import excise tax, special tax, import VAT, export customs procedures as well as other rules and regulations on internal market.

Phenomenology of behavior by which taxpayers avoid import duties can be shown in two main categories. The first one is non-declaration of goods at the border or smuggling across border. This is the most common type of irregularity and it causes the highest damage to the budget. The second category is made of manipulations with some normative features of goods such as type, quality and quantity as well as other data that is relevant for customs valuation. After research of different behaviors that are linked to avoidance of import duties, it turned out that above phenomenological dichotomy clearly shows two basic modalities of criminal offence that often different, but sometimes even overlapping. The best example is manipulation with the quantity of imported goods whereas we have false information about actual amount of goods as well as smuggling of undeclared ones. Same happens with the type or quality of goods. By declaring lower quality, importer actually smuggles other undeclared goods.

4 Law on Customs Policy of Bosnia and Herzegovina (Službeni glasnik BiH, 57/04), Customs tariff of Bosnia and Herzegovina is harmonized with EU tariff from 2006. Law on Excise Duties in Bosnia and Herzegovina (Službeni glasnik $\mathrm{BiH}, 62 / 04$ ), Law on Value Added Tax (Službeni glasnik BiH 09/05). 


\section{Smuggling}

Smuggling means taking a certain kind of commodity on which customs is due across the border without declaring it to the competent customs services.

The ways in which goods are smuggled are very diverse, ranging from classic smuggling by secretly crossing the border away from the border crossings, or hiding goods in concealed spaces, behind false walls, in lockers and other hidden places, via fraudulent declaration of a different kind of good, to complicated operations manipulating the customs procedures, documents or regulations.

The prevention of smuggling is above all an issue of the vigour of border surveillance and control of goods that pass over the border. Smuggling is most commonly part of illegal commerce, while budget is being damaged by customs evasion and by the loss of excises and value added tax.

In the most cases, highly taxed goods are smuggled, such as cigarettes and alcohol, for the sake of making a high unlawful profit by sales on well-organised black markets. For the same reason organised criminal syndicates channel the sale of smuggled goods towards the illegal markets of the countries with a higher tax rate. The channels for smuggling cigarettes and alcohol go along land, air and water routes.

The most widespread form of fraud is smuggling via the physical concealment of goods at border crossings or the declaration of the import of a different kind of commodity by fraudulent customs documents.

\section{Manipulation of transit procedure,} transit frauds

3. Fraudulent declaration of information relevant to customs

a. Fraudulent declaration of quantities of goods according to number or weight.

b. Fraudulent declaration of kind and quality of goods

c. False information about country of origin of goods

d. False information about purpose of goods

\section{Export frauds}

\section{Subsidy Frauds}

In order to carry out the programmes and policies, state from its budget, via funds and the national civil services, allocates to individuals and corporate entities financial sums in the form of subsidies, grants, premiums, incentives and other forms of assistance and financing ${ }^{5}$.

The subsidy system contains a number of criminogenic characteristics that, as numerous examples from practice will show, are hard for the average farmer to resist, while for firms and associations that want to make unlawful profits, subsidies are a real draw.

The largest number of manipulations with regard to the resources occurs, of course, in the farm sector and in the structural funds (Đurđević, 2006).

5 Some theorists and legal sources distinguish direct and indirect subsidies. Direct subsidies are taken to mean the allocation of financial assistance, and indirect subsidies are tax and other reliefs. In this paper, subsidy is taken to mean direct subsidies. 


\section{Subsidy fraud in the area of the agricultural policy}

a. Fraudulent production or export declaration

b. Fraudulent declaration of the quantity of goods, in number or weight

c. Fraudulent declarations of kind and quality of goods

d. False information about the origin of goods

e. Fraudulent information about country of export

f. Fraudulent declaration about the purpose of goods

\section{Subsidy frauds in the area of the} structural policies

One of the largest expenditure of the state budget goes into the structural funds for the financing of regional development and social policies via various economic, social, educational and other programmes. The structural policy budgetary resources are managed by special departments in national governments, and the member states have the ultimate responsibility for the financial control of the use of the moneyof these funds ${ }^{6}$. The most common forms of fraud with resources from the structure funds relate to the partial or total nonperformance of activities, or the non-performance of the obligations provided for by the financing of the programme, double financing, or multiple use of different sources of financing for the same purpose, and investing fund resources into currency speculations and other financial scams for the same of making a profit. Misspending in certain

6 For the way control is carried out by member states with respect to activities co-financed by the structural

funds, see Commission Regulation (EC) no. 2064/97 of October 1997. programmes is assisted by there being little number of cases being discovered, since it is difficult if not impossible to check the purposefulness or justification of every cost incurred in carrying out a given programme.

As an example of the fraudulent appropriate of resources from one of the structural funds, the literature often cites the case of fraud in the financing of programmes for employment in Greece, where nine producers received about 3 million euros of subsidies for creating new jobs. Instead of employing new workers, they sacked their old staff, and reemployed them in a newly founded firm with a new name.

\section{Types of vat Frauds}

Important asset of VAT system in relation to tax on movement of goods and services is that VAT system is self-controllable. VAT invoice is very important element in VAT system; because it is mechanism of control for companies, taxpayers and tax administration since input tax that is shown on the invoice of the supplier can be deducted from VAT obligation at the end of accrual time. If the amount of input VAT exceeds value of tax obligation, it can be claimed from the state. This is the reason why taxpayers' best interest is to receive correct invoice with VAT clearly stated. This invoice represents legal ground for tax return. The second important characteristic of VAT system that puts him in front of the system of tax on movement of goods and services is that it is multistaged tax which is being calculated and paid upon each transaction, from the production, to the import and final consumption. This feature in a great manner reduces chances and of tax evasion since it is paid partially in each phase, while on the other 
side we have system of tax on movement of goods where whole amount of tax could be evaded. In the phase of final consumption, total of VAT collected in all phases must correspond to the total amount of collected tax on movement of goods in final phase. Taking into consideration phases through which products are going, the best VAT collection can be expected during import or at the stage of final consumption, when tax rate is the highest.

There are two basic ways of tax evasion in VAT system (Antić, 2006).

"Activities outside VAT system" - smuggling and intentional avoidance of VAT system. There are companies that try to stay outside VAT system although they are liable to VAT system based on its annual turnover).

"Activities inside VAT system" - tax evasion, intentional reduction of VAT duties, showing of higher VAT input and asking for tax return.

Although VAT system has many benefits, there have been registered different ways of frauds with a single aim - unlawful usurpation of budgetary funds. This system is, same as customs system, characterized by unfulfillment of legal obligations that is to pay certain amount to the state budget.

Fraud in registration

\subsection{Avoidance of VAT registration}

a. Parallel companies

b. Separating businesses to avoid VAT

Reduction or understatement of output VAT

2.1. Non-recording of retail sales

2.2. Non-recording of services to the end user

3. Recording higher input VAT

3.1. Claims of input VAT for tax relief

3.2. Recording VAT by non-VAT liable companies

3.3. Forging supplier invoices

3.4. Non-recording of bookkeeping notes
3.5. Forging of export customs declarations

3.6. "Phoenix" companies

Multiple frauds

Usage of goods and services in business and non-

business purposes

Non-recording of supply or cash sales

Illegal import of goods and their sale with VAT

calculated in their price

Non-recording of sales to VAT payer.

Compensational arrangements

Evasion of collected VAT

Connected or associated companies

Carousel frauds

"Mistakes" in bookkeeping

Frauds in VAT system with multiple tax rates.

\section{CONCLUSION}

Issue of tax frauds and tax evasion does not stop being a part of everyday political debates. Knowledge and apprehension of what makes a fraud in system of indirect taxation is still limited, especially in regard to consequences of crossborder international crime.

The aim of this paper is to analyze and point out old and new dangers that stand in front of Bosnia and Herzegovina and the EU in regard to tax evasion, as well as to bring up the consciousness on this problem and to help legal entities that make policies in making decisions based on all facts about fight against organized crime. Hence, the conclusions can be summarized into following:

- fight against frauds in system of indirect taxation becomes strategic recourse of the state with the objective to increase revenues from indirect taxes, - legal harmonization, joint efforts in law enforcement, and exchange of information among 
law enforcement agencies in the region would be a REFERENCES

key to success in fight against these frauds,

- information technologies, modern shapes of criminal activities, organized and transnational crime force us to change current and adopt and use new methods of law enforcement,

- these frauds not only cause damage to the state budget, but also endanger functionality of internal market and financial as well as political system, - growing concerns over these frauds and future association to the EU call for serious analysis of scope, nature and features of these irregularities. Efficient activities should be based on scientifically based criminalistic policy that is capable of obtain positive outcome,

- type and level of damage that is caused by this crime should be a call for an action, for further research of this societal problem. Final goal is to prevent and combat this crime in more sufficient and successful manner.
- Antić, D. (2006). Abeceda prijevara u sustavu PDV-a [Alphabet of fraud in the VAT system]. ZIPS, No: 1054.

- Dautbašić, I. (2004). Finansije i finansijsko pravo [Finance and Financial Law]. Pravni fakultet u Sarajevu, B\&H.

- Đurđević, Z. (2006). Prijevare na štetu Evropske unije:pojavni oblici, metode i uzroci [Fraud to the detriment of the European Union: the forms, methods and causes]. Pravni fakultet, Zagreb, Croatia.

- Commission Regulation (EC) no. 2064/97 of October 1997.

- Zakon o carinskoj politici Bosne i Hercegovine [Law on Customs Policy of Bosnia and Herzegovina] ,Službeni glasnik" BiH, br. 57/04.

- Zakon o akcizama u Bosni i Hercegovini [Law on Excises in B\&H], Službeni glasnik BiH, br. 49/09.

- Zakon o porezu na dodatnu vrijednost [Law on Value Added Tax], Službeni glasnik BiH, br. 09/05. 